\title{
School and social development among the E'ñepá Indians of the Venezuela Amazon: an anthropological approach
}

\author{
Tarzycjusz Buliński
}

\begin{abstract}
In this article, I would like to test how accurate is the notion that school is one of the main factors in the social development of Indian communities. According to this view, school education improves the social, political, economic and cultural situation of the Indian peoples of South America. This is a position widely circulated among the national community in the region and is the basis for development programs and projects carried out among the IndiansI. I would like to examine to what extent this view is correct with respect to the E'ñepá Indians living in the Venezuelan Amazon. I approach the question of what impact schools have on the development of these communities from an anthropological perspective, and thus from the point of view of Indian social practices. The article consists of four parts. In the first part, I characterize the current socio-cultural situation of the southern E'ñepá and the activities related to school education among them, and introduce the reasons why I chose this people for my analysis. In the second part, I indicate a problem posed by analyses from within the dominant non-anthropological current of reflection on development, and present the anthropological approach to the issues referred to in the article's title. In the third part, I describe the development that is said to result from a school's operation according to the intercultural education program being carried out among the E'ñepá. In the fourth section, I show, based on the example of the spread of the practice of writing, how, by means of an anthropological approach, one can assess the real impact of the school on the social development of the Eñepá Indians.
\end{abstract}

Key words: Indigenous schooling, Eñepá Indians, writing, anthropological approach, developmental theory.

\section{Resumen}

\section{ESCUELA Y DESARROLLO SOCIAL ENTRE LOS INDÍGENAS E’ N̈EPÁ DE LA AMAZONİA VENEZOLANA: UNA APROXIMACIÓN ANTROPOLÓGICA}

En este texto intentamos verificar la hipótesis que sostiene que la escuela como institución (educación formal) es uno de los factores más importantes para el desarrollo social de los pueblos indígenas de América del Sur e influye sobre su situación social, politica, económica y cultural. Esta opinión es popular entre las sociedades nacionales y constituye la base para programas y proyectos de desarrollo de las sociedades indígenas. Verificamos si esta hipótesis es correcta en el caso de los èñepá de la Amazonía venezolana. Analizamos la influencia de la escuela como institución desde la perspectiva antropológica. El

Tarzycjusz Buliński - Instituto de Arqueología y Etnología de la Universidad de Gdansk; e-mail: tarzycjusz.bulinski@gmail.com 
texto contiene cuatro partes: 1) caracterización de la situación actual de los e'ñepá del sur, 2) descripción del problema teórico del método de análisis del desarrollo de tipo antropológico y no-antropológico, 3) característica del modelo de desarrollo social según el modelo de educación intercultural bilingüe en Venezuela 4 ) interpretación antropológica de la influencia real de la escuela para el desarrollo social de las comunidades éñepá.

Palabras clave: educación indígena, indígenas e’ñepá, escritura, enfoque antropológico, teoría del desarrollo.

\section{The E'ñepá Indians and the school}

The E'ñepá Indians (exoethnonym: Panare) are an ethnic group that speaks E'ñepá, a language belonging to the Carib language family. They are estimated to number more than 4,000 people (data from 2001 census), who can be divided, according to external criteria (i.e., anthropological), into three regional groups: the western, central and southern E'ñepá (Dumont 1978; Henley 1982, 1988). However, according to internal criteria, the indigenous people called the E'ñepá do not exist as a single whole (the word itself does not denote an ethnic group, but simply "people»), and group identity is formed at the local group level using the criterion of kinship and the practice of building a common body (consubstantiality). Individuals who might appear to be members of the same people are perceived by their "brethren" as outsiders, like other Indians (the Piaroa or the Yekuana) inhabiting the area. Therefore, talking about the E'ñepá as a defined whole is a simplification.

The southern regional group of the E'ñepá, among which I conducted my research ${ }^{2}$, populates the basin of the Cuchivero and Ventuari Rivers in the Venezuelan Amazon. They number some 1,500 people, comprised of two collections of local groups (in Guaniamo and Cuchivero), which remain geographically, culturally, socially and economically largely isolated from Venezuelan society. Although the Indians established ongoing relations with members of the so-called national community, so-called criollos $^{3}$, in the 1950 s, these have mainly been with local cattle farmers (llaneros) and two Catholic missions (one local group also had a shortterm relationship with the Protestant New Tribe Mission). There are no large-scale economic institutions operating on their territory, with the exception of a diamond mine located near one of the settlements, which reached the peak of its activity in the 1970s and 1980s. Despite its proselytizing activities, the Christian religion plays no role in the lives of the E'ñepá, there have been no converts or Indian priests, nor have any church buildings been constructed. The first Indian organization - Asamblea del Pueblo Éñepá - was only founded in 2001. The E'ñepá are a fully egalitarian society, and there are no government institutions among them except for one that is a facade - the position of social leader of a settlement, el presidente, adopted for the 
purpose of maintaining relations with the criollos. The Panare Indians are semi-nomadic thus they change the place of their settlements usually every several dozen years (typically 30-40 years). The size of settlement depends on the development cycle of the local group, and ranges from several dozen to several hundred people. Whether or not the community remains in one place is dependent on factors that are social (the importance of emotional ties linking members of the village) and economic (the wealth of the natural environment) in nature. In 2009, there were nine local groups (settlements). Their subsistence was based on hunting, gathering, and slash-and-burn agriculture. Moreover, the E'ñepá are occasionally hired to perform the work for llaneros in the surrounding area. They are totally independent economically.

School education arrived to the E'ñepá in the late 1960s with the establishment of two missionary institutions run by sisters of the Order of Las Misioneras de María Inmaculada y Santa Catalina de Siena (locally called hermanas lauras): the first was closed a little more than two decades later, the second one, founded in 1982, is still in operation. Initially, they were mission schools, with nuns acting as teachers. The program they carried out can be described as learning aimed at moulding students into Catholics and citizens of the state. With the opening of a state school (1979), teaching duties were assumed by indigenous E'ñepá teachers. Education extends only to preschool education (la educación prescolar) and the first six years of primary education (1-6 grado de la educación basico). The curriculum initially did not differ from that of other rural school programs (la educación rural), but since 1992, a program of intercultural education has been implemented, geared towards protecting Indian language and culture. In 2009, among the southern E'ñepá, there were six schools located among six local groups. Sixteen male and female teachers taught in them. The number of children enrolled in school is very high; for example, in the 2008-2009 school year, this number included 90,6\% of school-aged children.

As is clear from this brief characterization, the situation of the southern E'ñepá is quite unique. As we know, in the mainstream of non-anthropological thinking on development and its design - manifestations of which can be seen at both the national (government programs) and international (the programs of organizations such as UNESCO or the World Bank) levels - three types of modern institutions are most commonly pointed to as providing incentive for the development of indigenous communities. These are institutions and practices associated with the economy, healthcare, and education (for examples of the latest documents, see: Hall and Patrinos 2006; López 2009; Martínez and Fernández 2010). From this perspective, the southern E'ñepá seem to be a good case for examining the accuracy of the belief that school education has a positive impact on the development of Indian communities, because the school is the only modern institution that has operated among them continuously for 40 years. The presence of other state and non-state economic and healthcare institutions among the southern E'ñepá is, in 
practice, negligent because of their considerable isolation from Venezuelan society. So if a school education entails any changes, these can be seen there more easily, given the absence of other developmental factors, such as major economic investments or an effectively functioning health care system. In other words, if the school has a positive effect on the development of Indian communities, this should be visible in the southern E’ñepá.

\section{Problems studying the impact of the school on social development}

Yet, how can this impact be studied? This can be done in at least two ways: non-anthropologically and anthropologically. This division is obviously a working model, and makes no claim to being conclusive. Its purpose is to highlight the difference between these two types of research approaches.

The first, non-anthropological approach is represented by sociologists, educators and political scientists (for examples concerning the Indians of Venezuela, see: Pérez de Borgo 2004; Regnault 2005, 2006; Monsoyi 2008). The role of schools in Indian communities is considered here by means of external, non-indigenous criteria and cognitive tools. These are frequently called development indicators, and thus a phenomenon that external researchers have considered a basis for assessing if development has actually occurred. They usually relate to variables in three areas: the economy, healthcare, and education. Studies following this approach are mainly concerned with tracking quantitative changes in the communities surveyed. They show how wide is the distribution of Western-type medicines among the Indians, if new techniques related to the cultivation of crops, transportation, hunting, and home construction have been adopted, if political activity among the Indians has increased, etc. In one word, they juxtapose two types of variables: school education and the introduction of new social phenomena that the authors associate with improvements in the social, political and economic situation of the Indians themselves (and therefore their social development).

The basis for this type of work is a concept that, for purposes of this text, I will call the popular concept of social development. According to it, an indispensable step to community development is the development of the individual. For individuals to improve their living conditions, and thereby achieve social advancement, it is necessary for them to develop cognitively and, colloquially speaking, broaden their horizons. This is achieved by learning the formal skills taught in school known as the "three Rs»: reading, writing and arithmetic, in other words, textual and mathematical literacy. What is being assumed here is that the cognitive development stimulated in individuals by the school results in transformations in their consciousness and worldview, and thus, changes in their aspirations in life. Through education, opportunities for participation in the national economy and the structures of the nation-state are increased. Educated people begin to change their 
financial, social and political situation. The more individuals do so, the more it leads to the development of the community as a whole ${ }^{4}$; hence, the importance attached by various institutions to rates of school enrolment. A typical example of such a research strategy, intellectually grounded in the popular notion of development, is to point to growth in the ability to read and write among Indians, and then show how it affected their personal and social development (see e.g.: Dagett and Wise 1992; Davis 2002.)

Despite its popularity and the numerous advantages of the non-anthropological approach, it is accompanied by several methodological problems, of which I will mention here only the most important, that is, studying a phenomenon without taking into account the context in which it occurs. Let us begin with an example. In order to assess the foundations of the popular concept of social development, numerous studies have been conducted in various regions around the world with the aim of evaluating changes in the cognitive skills of people based on the level of school education they received. These were usually conducted using a testing method that relies on psychological testing of the person being investigated, and on the basis of this, assessing the level of his cognitive skills. Classic examples of this procedure are tests of memory, problem-solving abilities, and mathematical skills. The problem with this type of research is that it is burdened with methodological weaknesses - they assess the level of cognitive skills using research techniques based on the cognitive skills taught in school. In other words, they measure the correlation of a seemingly neutral phenomenon (cognitive skills) with another seemingly neutral phenomenon (school education) with measurements (tests) that are de facto based on the second phenomenon (the correct solution to tests requires abstract thinking, which is taught exclusively in school). It is no small wonder that people from other cultural contexts, who are relatively unfamiliar with the type of thinking associated with knowledge acquired in school, achieve worse results on these tests than their counterparts who have already been introduced to the culture of the school. This led investigators to the erroneous observation that a school education contributes significantly to improved cognitive development in the individual, whereas in the light of other research, it merely led to the acquisition of specific knowledge and socio-cultural practices associated with the institution of the school (Sharp et al. 1979; Rogoff 1981; Scribner and Cole 1981; Cole 1990).

Not taking into account the context in which a phenomenon occurs can result in improper conclusions being drawn. Moving to a more general level, we can say that the weakness of the non-anthropological approach is its use of a modern, non-indigenous concept of "development" to determine the level of development in Indian communities; however, these are disproportionate variables. In empirical studies, the researcher is usually interested in quantitative data - development occurs when there is an increase in some factor, such as the level of literacy, the introduction of new techniques (in terms of transport, construction, treatment, etc.) or social practices characteristic of the national community (a meeting of the comu- 
nidad devoted to discussing things important to it as a whole, so-called reuñones). However, in the conclusions reached by these studies, quantitative variables are used to determine qualitative changes - for example, higher levels of literacy demonstrate an increase in the awareness of those studied, the increased popularity of new techniques for cutting down trees or treating diseases demonstrates the modernization of Indian communities, the universality of reuñones demonstrates development in terms of ethnic identity in the colloquial sense of that word ${ }^{5}$. This problem is quite significant: on the basis of some selected aspect of Indian reality, researchers judge whether or not the Indians demonstrate any social development. Meanwhile, they show no concern as to the context of this aspect of reality, nor do they consider the Indian's motives, or the legitimacy of the practice as part of their indigenous way of life. In other words, the researchers define development according to their own fashion, and search for development that fits this shape. It is no wonder they have no problems finding it. This can lead, on the one hand, to unwarranted interpretations of facts; on the other, it makes it much harder to see the real impact a school has on an Indian community.

One solution to this problem is to take another route to studying the impact of education on social development - an anthropological approach (related to social or cultural anthropology). What does this mean? In brief - it means looking at the issue of the school from the perspective of the Indians themselves.

Of course, there are several characteristics of the anthropological approach to explain, of which the most important one for us here is the requirement to consider the context of the phenomena being studied. This manifests itself both in considering the historicity of the analysis (it always concerns a concrete «here and now"), and in the presentation of the subject's perspective (this includes how the people being studied understand and interpret a given phenomenon.) Yet the mere presentation of the point of view of the Indians on the school is not enough. This strategy recognizes their ideas and schemes of interpretation, but it does not help to estimate if the school has had any real impact. In this way, we merely learn how Indians perceive the practice of school (such approaches are already present in anthropological literature; see e.g. Aikman 1999; Gouvêa Collet 2006; Lopes da Silva Macedo 2009a; Tassinari and Cohn 2009). But how can we see whether the school has really impacted the development of a local community without either imposing our own way of looking at this issue, or failing in our response to present the Indian point of view?

An alternative is to examine the influences of the school from the perspective of the social practices of the Indians. This concerns three groups of things: (1) the vision of development contained in the premises of the educational programs, in particular, the social phenomena whose appearance is to signal development, (2) new social phenomena among the Indians that occurred after the introduction of school education, (3) the image of these social phenomena in the light of Indian social practices. In 
this way, we obtain an interpretation that is infected by non-indigenous categories to the least extent possible. This is the strategy I propose adopting here ${ }^{6}$.

Based on the example of writing, I will show that new practices include features that call into question their «developmentalness», and that in looking at the shape of the phenomenon meant to be proof of social development, one can see something else: that it is a transformation of the Indian strategy of being in the world, an adoption of new practices for the achievement of indigenous goals.

\section{The school as social development according to the Intercultural Education Programme}

Let us now look at what kinds of social changes a school education should lead to according to El Regimen de Educación Intercultural Bilingüe (the bilingual intercultural education program; hereafter EIB). These are outlined in the form of goals for Indian schools and teachers that indicate what social development among the Indians of Venezuela is to be based on. The EIB was introduced in Venezuela 1982 , and although it has undergone various changes since that time, it continues to function in the state education system. It has been implemented among the Ëñepá since 1992. Its reconstruction here is based on official documents (e.g. Ministerio de Educación 1988; Dirección de Asuntos Indígenas/Ministerio de Educación 1998), publications by the authors of the program (e.g. Mosonyi and Rengifo 1982; Mosonyi 1998; Mosonyi and Mosonyi 2000) and texts by other authors of the EIB (e.g. Villalón 1994; Moreno 2000; Vega 2000; Villa 2000). The vision contained therein reflects to a large extent the image of social development that representatives of Venezuela's national community have imposed on Indian schools and Indian teachers?

According to the EIB, the school should help achieve two objectives. The first is social equality between the Indians and other members of the national community. According to the vision of the proponents of the EIB, school education among the Indians has currently led to their acculturation and their «creolization». The school thus functions as an instrument of Venezuelan nation-building - creating people who would identify with the state and mainstream society, and abandon their Indian heritage. The result of this has been the reinforcement of paternalistic attitudes, according to which Indians are inferior, second-class citizens, who do not know the Spanish language, look different, and are not versed in the world of the criollos. For this reason, the EIB also prioritized the idea of bringing indigenous groups into mainstream society without depriving them of their specific character. The school would no longer be an instrument of domination over the Indians, but a tool for providing assistance, with which they could more easily participate in the social, political, and economic processes of the national community. They should be Indian citizens (los ciudadanos indigenas), who besides feeling they are Venezuelans, are also conscious of their indigenous identity, seeing it as a positive thing and working to preserve it. 
The second goal, subordinate to the first, is a positive valuing of indigenous culture and introducing into educational the idea of a multicultural society. How? Through language. According to the main ideas permeating the EIB, Indian culture resides in the Indian languages, and the core of the EIB has been teaching the mother tongue of a given ethnic group. Thanks to this, Indian culture could be defended, or animated in those cases where - according to the EIB - acculturation had already begun to reap its harvest. Since that time, Indian and Venezuelan content were to have been equally important in the curriculum carried out among the Indians (multiculturalism). Emphasis was placed on teaching the native language in the early stages of learning (the first three years of primary education, $1-3$ grado), introducing as subjects the history and geography of the indigenous people, their native crafts and "sports" (so-called deportes indígenas), and above all, reading and writing in the native language. A key role was played in this by Indian teachers. In the first stage, they had to help Venezuelan linguists and educators create an alphabet for their language group, then create school textbooks in this language, and finally begin to act as group leaders. How? By teaching the "culture" of their own group in school, activating the community in matters of preserving their heritage (e.g. reuñones), and taking part in the activities of organizations that brought together Indians from different groups who were fighting for the same causes (e.g., property rights to their territory). In one word, the teacher was to be a builder of the group's ethnic identity, and the school, the centre of the comunidad.

As one can see, the EIB offers a vision of two types of social development: Indian and pro-state, resulting in contradictions, which its critics have eagerly pointed out (e.g. Villalón 1994). However, for our purposes it is more important to note that within this picture an active role is played only by the representatives of the national community, to the exclusion of the Indians. It is the party that decides what form the schooling will take, and it determines the fate of the indigenous cultures and the Indians themselves. If the approach to the school is accultural, then a school education will lead to a loss of ethnic identity within the meaning of the EIB. If the school is geared towards multiculturalism and multilingualism, the Indians can preserve their culture. Indians function here as passive objects of the learning process. Activity is shown only by those who have already been affected by the development process - Indian teachers. A school education is thus a primary factor for change.

In summary, according to the EIB, Indian schools and teachers exist to impart valuable knowledge (literacy in the indigenous Indian and Spanish languages, the ability to count, knowledge of the Indian world and the world of the criollos), and thus develop valuable attitudes (about society, politics, and economic equality, the valuing of Indian «culture»). Their presence is confirmed by new social phenomena. The EIB does not specify what these are, although a number of formulations of them ${ }^{9}$ indicate that they primarily concern (1) increasing the participation of Indians in the life of the national community, and (2) the emergence of Indian 
teachers as a modern elite in the Indian community. On the basis of the two, one can state more or less whether or not the Indians have acquired practices that benefit the national community. One of these is the ability to write.

\section{Writing practices among the E'ñepá: an example of the impact of education on social development?}

This section will demonstrate how the anthropological approach can be used to estimate the real impact of the school on the social development of the E'ñepá Indians, using as an example the phenomenon of the spread of the practice of writing.

In the first half of the twentieth century, there was likely not a single person among the southern E'ñepá who could write -no such person can be recalled by even the oldest living Indians. From the standpoint of development programs, the E'ñepá of that period would have been classified as illiterate. The situation at the beginning of the twenty-first century is radically different- the majority of the population knows how to write to varying degrees. To demonstrate the scale of the phenomenon, we can use the village of San Gregorio as an example. In 2007, its inhabitants numbered 227, of which 54 were small children in preschool, and 10 were elderly people who had never attended school and could not write. The rest could be divided into two groups: (a) individuals who were attending or had attended school at the primary level, some of whom did not finish it (141 people) and (b) individuals who were continuing or had continued their education at the secondary level (21 people). The first group, by far the largest, includes those who learned to read and write by attending school for several years (the period of schooling varies from four to seven years), and whose knowledge of writing consists of the ability to sign their name and write individual words, while they have problems writing sentences. Development programs would probably classify them as functional illiterates (i.e. people who lack the writing skills to properly function in the day-to-day life of the national community). The second group are people who know how to write sentences (from simple to compound-complex ones), of whom some use writing in their daily lives - primarily teachers. Development programs would classify these people as literate.

This shows that the quantitative change was very significant. One can make a cautious estimate that roughly $71 \%$ of the population today can write (and another $24 \%$ will learn to do so in the near future) to varying degrees, and can do so in two languages: Spanish and E'ñepá (the presence of Indian languages as a teaching subject is a result of the implementation of the EIB program). But does this translate into development? The popular concept of development implies that acquiring literacy has a positive effect on the cognitive development of the individual, and this in turn entails economic, social and political transformation. Thus, according to 
this concept, a school education results in changes in the consciousness of individuals, and as a result of acquiring these new cognitive tools (writing skills), changes in the way the Indians conceptualize the world. The level of writing ability should therefore be positively associated with at least two new social phenomena: (a) a new worldview, and (b) the use of these new writing skills in everyday life, at least within the scope proposed by the EIB, and thus in an increase in the participation of Indians in Venezuelan society (the first goal) and the formation of an ethnic identity (the preservation of ethnic identity according to the terminology of the EIB) (the second goal).

Let us examine the first issue (the worldview), and then the second (the use of writing skills). In terms of the Indians' worldview, there is a strong disparity between what educated Indians, especially teachers, say about the criollos in face-toface conversations with representatives of the national community, which is unnatural for the Indians, and what appears in their spontaneous utterances during everyday situations. In the first case, they use a specific set of Spanish phrases, which I will refer to here as a discourse. The most common is the discourse of «culture», in which they talk about "their land", «their heritage», «their culture», and «their habits" -all of which is «worth protecting» and «fighting for». In other discourses, there appear phrases such as «school gives children a better future» or «we work hard to develop the community». This suggests that they think like the criollos, that they perceive the world and the mechanisms present in it like other members of Venezuelan society. From this perspective, state institutions can be used by citizens to improve their lives, and other criollos, other Indians, are people just like the E'ñepá - they all differ from one another only in terms of their «culture» - their language and customs - but they way they participate in the national community is similar. For example, everyone perceives the school as a practice that provides useful tools (knowledge) that enable improvements in their lives.

But this combination of spoken statements and social practice raises doubts in and of itself about whether this is the case. For example, during a conversation I had with a teacher named Josefina, she began with the discourse of «culture» cited above, then smoothly proceeded to a discourse of complaint, in which she depicted the work of a teacher in the comunidad as a continuous struggle with the reluctance of parents towards any form of activity, and with the laziness of pupils. However, in response to my questions about the performance of specific activities by specific students (e.g., homework), and about specific events (e.g., the number of parents at the last meeting, who prepares the meals at school for pupils, who moved the school furniture), a picture emerged of active, hardworking students and parents eagerly participating in school activities. This is a typical example of a conversation between an Indian teacher and a criollo in a situation that is unnatural for the Indian. It seems that the discourses used by the E'ñepá in such cases have either little connection to their everyday practice, or that this relationship is not at all important to the Indians. 
The spontaneous expressions of these same teachers in everyday situations revealed yet another aspect. For example, Gregorio, a medical worker giving patients factory-made medications, situates the ethology of the disease in the actions of a particular master of animal species, a supernatural being that could be experienced only by the soul of body (a type on internal body). In another example, Horacio, a teacher with a high school diploma, sees the cause of his ill health in the witchcraft of an Indian from another group who lives in his dormitory, and to whom he clearly assigns non-human characteristics. Horacio also described in two different ways the reason for which a school was moved to a new site after the tragic death of one of its pupils. In a situation of the first type, a face-to-face conversation with an anthropologist, he used a discourse of "culture», claiming that the school was moved because "these are our beliefs" and "to pay due respect to the memory of the deceased». In a much more intimate situation, during a relaxed, informal conversation about various matters, he spontaneously stated that the reason for moving the school lie in a real danger posed by the kochón of a deceased person (this is, an active residual part of the body, that occurs in the form of a shadow which resides in places where the deceased often spent time while alive. It is particularly dangerous shortly after death). From these examples alone, it appears that teachers do not differ from other E'ñepá and represent a way of seeing the world that is proper to many Amazon Indian peoples, and that their knowledge of the criollos' world is structured in the same way as their knowledge about the world of corporally invisible masters of animal species ${ }^{10}$.

To sum up this thread, one can see that the level of literacy does not translate into a transformation in worldview. The most educated Indians, even those who have a secondary school or university education, look at the world and interpret it in the same way as people who cannot read and write, and like - most probably the E'ñepá did before the introduction of the school in the first half of the twentieth century.

Let us now consider the process by which literacy was spread from the perspective of Indian social practices, beginning with some facts. First of all, the E'ñepá willingly engaged in the activity of learning to write in the classroom. Almost the entire population has experienced both the school and the writing activities associated with it. This occurred at the initiative of the Indians, and not the nuns and other criollos. It was the Indians who built the school buildings, provided the nuns with food and assistance, and encouraged their children to attend school. In the first years of the school's existence, adult male E’ñepá often also attended classes, had their own notebooks and wrote in them. This means that for the E'ñepá, as indeed almost everywhere in the Indian Amazon, the practice of writing in the place where they lived was a desirable fact.

Secondly, it was more important for the E'ñepá to learn to write from Indian teachers than from criollos. The span of 40 years shows how the Indians gradually 
worked to reach a state in which all the teachers were E'ñepá, and ideally, the teacher would be a member of his own local group, «their teacher», so to speak. Few Indian children are taught in schools located among criollos in neighbouring settlements.

Thirdly, the ability to write is not at all used outside the context of the school. During the lessons, the teachers write on the board or in the student's notebooks, when filling out educational documents, such as certificates, reports and forms, when drawing up schedules for lesson pans, kitchen duty, and classes, as well as in preparing financial documents. Apart from these instances, they do not engage in writing practices. Students do not write outside of school, and school tasks are not performed at home. There is no practice in the use of writing to communicate information. The E'ñepá do not write letters, although they comprise a highly mobile society where people are in constant motion, and often spend no more than several weeks in one place. From the standpoint of the criollos, in many such cases writing letters could prove useful, especially when particularly long distances are involved, or when information could be passed along by a third party. Yet, the Indians do not use writing for this purpose.

Fourth, the ability to write (and read) in Eñepá is completely «dead». Outside of the classroom, E'ñepá does not function as a written language. This is worth noting because according to the EIB, it is Indian languages, in their spoken and written form, that are to be the main instrument for positively valuing what the EIB considers «Indian culture». (In the case of the E'ñepá, for the criollos working with them, their «culture» is mainly their language, selected fragments of mythology, their way of dress, marriage customs, initiation rites and plaited goods.) The southern E'ñepá, however, seem completely uninterested in creating a so-called «Indian literature» - written materials in their own language that could later be used in conducting political activities outside their own community with the criollos world and other Indians. One can hear that written Ė̉epé is important only when listening to the discourse of «culture» that the E'ñepá use in their contacts with the criollos world. Looking at their social practice, we see something else - that writing is irrelevant to the Éñepá.

Fifthly, the E'ñepá seem to attach little importance to the effects of their (or other people's) writing, though they attach a good deal of significance to the operation of writing. They do not collect books or newspapers, do not read them, and one could even say that they do not take care of them. School textbooks and exercise books are not stored in any special way, and in the climate of the Amazon are quickly ruined. The same applies to documents associated with the institution of the school, such as pupils' graduation certificates, reports, etc.

These are some of the easiest differences that can be seen in how the practice of writing has been assimilated by the Indians. The E'ñepá, even those who are educated, do not use writing in their relations with the criollos or Indians from other ethnic groups outside the context of the school. They also do not use it in their 
contacts with one another. They use it only in the context of the school, and under certain conditions mentioned above. These differences in the writing practices of the E'ñepá suggest that writing has a different meaning for them than it does among members of the national community.

A clue can be found here in the meaning of the indigenous terms used to describe acts of writing. Among the E'ñepá from the Cuchivero the word I heard most often was yasaminka (other local variants include asaminka, isiminka, yameñkë) ${ }^{11}$. It indicates the act of writing on a piece of paper or board, but is also used to describe the activity of learning anything (aprender in Spanish), learning activities associated exclusively with the school building and school practices (estudiar in Spanish), and less often the term describes the school building itself and what the teacher does at school. It is thus an ambiguous term. Yet, what is most important is that its root refers to another native term - yamanë, or drawing activities, the marking of designs, letters, or patterns on a surface. A related term, yamen or tyameñ, is used to denote drawings, lines, or patterns of colour on the skin, such as those on a jaguar, but it also indicates the manner in which the Ejnepá Indians paint themselves during ceremonies, where these paintings transform the body to which they are applied, making it stronger, more vital, healthier, and more human according to the understanding of the E'ñepá. The extensive referential value contained in the word the E'ñepá chose to use to define a new, previously unknown practice suggests that writing is for them something very similar, or even the same as drawing/painting, that it is linked with knowledge, people affecting themselves, and the transformation of/building of a human being.

In the literature on the Amazon we find confirmation of this fact. Among the other peoples of the Indian Amazon, writing is identified with graphia, or the practice of applying designs (coloured and/or graphic) on the surface of any object for purposes of transforming it, appropriately shaping it (see e.g., Vidal 1992; Lopes da Silva Macedo 2009b; in terms of writing in schools, see Gouvêa Collet 2006). This applies both to objects (e.g., paintings on dishes, clothes, tools, homes) and people (e.g., paintings or tattoos applied to the body). As indicated by Lopes da Silva Macedo (2009b), the practice of writing is similar to shamanic practices in which there are interactions with other supernatural beings in order to obtain from them desired goods or activities (healing, improving the results of hunting activities, crop growing, etc.). When writing in Spanish or Portuguese, this concerns establishing relationships with Whites (and therefore criollos in the case of the E'ñepá) in order to obtain a tangible or symbolic result (the Indians do not make use of such a division) necessary for the reproduction of the group.

There is thus a high probability that for the E'ñepá writing in school is an extension of the practice of body painting and applying colour to objects (clay pots, loincloths, tools and weapons, etc.). It is not about the acquisition of writing skills that can later be used to transmit knowledge (this is the criollos point of view). The 
practice of writing in school needs rather to be looked at like drawing. Students do not so much write letters, words, and sentences, as draw patterns. More accurately, they copy them. This explains, for example, the fact that the teacher carefully rewrites/draws what is in the book on the blackboard, and students carefully copy/ draw the letters, words, and sentences from the board into their notebooks. This is also why what is important is the impression of the act itself on the person performing it, rather than its effect in the form of writing on paper or the blackboard. What is important is what happened during the practice to the person who wrote/ copied. For this reason, it is important for the E'ñepá to have their own teachers and why writing is limited to school, because it is the safest way to communicate with external beings, to which criollos belong - by allocating to them the appropriate space and people - those who are already experienced in interactions with foreign beings. This is exactly what occurs in the case of shamanic practices. So, in the end, the E'ñepá language is completely ignored in school education - it is not of external origin, not of the criollos. The knowledge necessary for reproduction always comes from outside.

One should therefore see the practice of writing more as a process that occurs within those practicing it, than as a skill one can learn and use. Most likely, writing for the E'ñepá is not a skill or transfer of knowledge. Thus, it cannot function in the way those who created and carry out the EIB imagined. This interpretation allows for a better understanding of the specific features of the practice of writing among the southern E'ñepá. It also shows, that it is hard to acknowledge the spread of the practice of writing among them as an example of an entirely new social phenomenon that could be taken as an indicator of their social development. Writing is clearly associated with the school and teachers, but its existence alone has not initiated the processes of development that the representatives of the national community had in mind.

\section{Conclusion}

As we can see, the spread of the practice of writing among the E'ñepá did not lead to the expected developmental effects. Therefore, the mere presence of a new social phenomenon does not determine the existence of social development. The shape that the Indians have given to it as part of their social practice suggests, that from the standpoint of the E'ñepá its «newness» is illusory. Writing in school is an extension of the practice of forming people using practices derived from the external beings living around the E'ñepá. However, the absence of features that criollos themselves find useful in writing shows that this practice had not taken a form that is modern or appropriate for representatives of the national community; it shows that writing for the Indians is not a cognitive ability or a means for managing knowledge. The conclusions that result from this require that we treat with caution the 
theses advanced by scholars who make claims about the social development of Indians solely on the basis of the existence of new social phenomena. To determine to what extent such theses are reasonable, we need to take into account the Indians' indigenous strategies for acting in the world, and what place the new social phenomena occupy within this.

\section{Notes}

1 The visions of social progress behind the work of activists and reformers calling for the introduction of various models of education for Indian communities have varied considerably, depending on the region and the historical period. For simplicity, they can be grouped into three types of social progress caused by the school: (a) proselytic, where school education has led to the adoption by Indians of the Christian religion, (b) pro-state, where it is meant to produce citizens who will participate in the life of the state, and (c) Indian, where its goal is to build and protect the ethnic identity of Indians. Of course, all of these have been formulated by members of national communities, and do not take into account indigenous perspectives or indigenous archetypes of well being (the Indian equivalent of the category of «development»).

2 The research was carried out between 2001 and 2009. They were funded through two grants: Primeval Cultures in a Modern World (grant from the Scientific Research Committee, 2000-2003) and Indian Attitudes Towards the School (grant from the Ministry of Science and Higher Education, 2006-2008). All personal data and names of settlements in the text have been changed.

3 The term criollos (creole) is widely used in Venezuela to describe Venezuelans. It has no racial connotation, and is applied to both whites and mestizos. Of course, in a formal sense, the E'ñepá are also Venezuelans, and thus citizens of the Venezuelan state. However, in the social and cultural context, the E'ñepá are clearly distinguishable from other groups comprising the national community.

4 One basis for the popular conception of social development is the way of viewing the relationship between the practice of school education, the ability to read and write, and the development of individuals and societies, the legitimacy of which is defended in mainstream works in literacy studies (see e.g.: Goody 1977; Olson 1994; for a critical example, see: Street 1984).

5 The common understanding of ethnic identity refers to a vague sense of "culture» in a given group. It is most commonly identified with an ethnic language, fragments of mythology presented as a group's oral tradition, selected social practices (e.g. initiation) and certain aspects of so-called material culture (e.g. decoration, costumes and music). It is worth noting that the anthropological concept of ethnic identity is different. For the anthropologist, ethnic identity is a kind of tie that binds members of a community, which refers to their ties as an imagined community, based on a set of judgments, beliefs, and values, as well as activities associated with festive occasions. This type of identity formation among Amazonian Indians is a long-term process related to the presence of the first colonial, and later, nation states (see e.g.: Whitehead 1992). This earlier type of group identity linking Indian groups is usually referred to in anthropology as cultural identity.

6 The author of this idea is Mariusz Kairski, a researcher with whom I conducted field research among the southern E’ñepá. See footnote no. 2.

7 This is confirmed by two sources. The first of these are conversations and observations I conducted during my research on Venezuelans involved with education among the southern E'ñepá. The second are items in the literature concerning the Indians of Venezuela, from which on can reconstruct the image of social development held by representatives of the national community working with the Indians. This primarily concerned the Yanomami, whose situation is in many respects similar to that of the southern E'ñepá (see e.g. Kelly 2004; Marchán 2005). In both of these sources a picture of social development emerges that is similar to the vision of the EIB.

8 The EIB operates according to a colloquial understanding of culture and ethnicity. To distinguish it from an anthropological understanding of culture, I will write the word in quotation marks. See footnote no. 5 . 
9 Such as this: «(...) the success of the educación intercutural bilingüe will make it possible to achieve the goal of people becoming interested in improving their economic situation and in ethno-cultural renewaln (Mosonyi and Mosonyi 2000: 95).

10 A perspectivist way of seeing the world can be summarized in a nutshell as follows. (1) First, the world according to it is fully socialized, all beings experience it from the same human perspective, and consider themselves to be human beings. Humanity is not a state reserved for certain entities ('people' according to the Euro-American world view) and inaccessible to others ('animals' according to the Euro-American worldview). (2) Second, humanity is processual, impermanent and transitory. No one is born a human. It is a qualitative state of being of a subject, the formation and maintenance of which requires great effort from him. One is human only through action, through agency and intentionality. This condition can be both achieved and lost. (3) Third, humanity is relational. The same subject is more or less human depending on the being with which he interacts. A subject changes its ontological status as the result of it relations with each being encountered. This relation is effected by who is the predator and who is the victim, and where the relations are more equal, this question remains open (see e.g., Lima 1996; Vilaça 2002, 2005; Viveiros de Castro 1998, 2002).

11 Among the E'ñepá regional differences are significant in linguistics terms. The E'ñepá language varies considerably depending on the regional group, primarily semanticallybut also grammatically. The commentary I have made here concerns the language of the E'ñepá Indians living in the basin of the Cuchivero river. The fact that as a basic term to describe "writing" I used yasaminka, and not asaminka or isiminka is merely a result of my own personal experience in the field.

\section{References cited}

Aikman, Sheila

1999 Intercultural education and literacy. An ethnographic study of indigenous knowledge and learning in the Peruvian Amazon. 232 pp. Cole, Michael

John Benjamins Publishing Company, Amsterdam/Philadelphia.

1990 Cognitive development and formal schooling. The evidence from cross-cultural research. In Vygotsky and education. Instructional implications and applications of sociocultural psychology, edited by Luis C. Moll, pp. 89-110. Cambridge University Press, Cambridge.

Dagett J. and M. R. Wise

1992 The social consequences of literacy in some ethnic groups of the Peruvian Amazon. Notes on Literacy 18 (4): 1-14.

Davis, Patricia

2002 Los machiguengas aprenden a leer. Breve historia de la educación bilingüe y el desarrollo comunal entre los machiguengas del Bajo Urubamba. 113 pp. Pontificia Universidad Católica del Perú, Lima.

Dirección de Asuntos Indígenas/Ministerio de Educación

1998 Régimen de Educación Intercultural Bilingüe: Diagnósticos y Propuestas 1998-2000. Dirección de Asuntos Indígenas (DAI)/Ministerio de Educación, Caracas.

Dumont, Jean-Paul

1978 The headman and I. Ambiguity and ambivalence in the fieldworking experience. 211 pp. University of Texas Press, Austin. 
Goody, Jack

1977

The domestication of savage mind. 192 pp. Cambridge University Press, Cambridge.

Gouvêa Collet, Celia L.

2006

Ritos de civilização e cultura: a escola bakairi. $374 \mathrm{pp}$. Ph. D dissertation,

Programa de Pós-Graduação em Antropologia Social - Museu

Nacional, Universidade Federal do Rio de Janeiro, Rio de Janeiro.

Hall, Gillette and Harry A. Patrinos

2006 Pueblos indígenas, pobreza y desarrollo humano en América Latina 1994-2004. 304 pp. Banco Mundial/Mayol Ediciones, Bogotá.

Henley, Paul

The Panare. Tradition and change on the Amazonian frontier. $263 \mathrm{pp}$. Yale University Press, New Haven/London.

1988 Los e'ñepa. In Los aborígenes de Venezuela, edited by Walter Coopens y Bernarda Escalante, pp. 215-306. Etnología contemporánea 3. Fundación La Salle/Instituto Caribe de Antropología y Sociología, Caracas.

Kelly, José A.

2004 Relations within the health system among the Yanomami in the upper Orinoco, Venezuela. Ph. D dissertation, University of Cambridge, Cambridge.

Lima, Tânia S.

1996 O dois e seu múltiplo: reflexões sobre o perspectivismo em uma cosmologia tupi. Mana 2 (2): 21-47.

López, Luis E.

2009 Reaching the unreached: indigenous intercultural bilingual education in Latin America. 60 pp. Background paper prepared for the Education for All Global Monitoring Report 2010. United Nations Educational, Scientific and Cultural Organization (UNESCO), Paris.

Lopes da Silva Macedo, Silvia

2009a Alteridades identitarias o como los amerindios wayãpi se relacionan con la escuela. Inter.c.a.mbio 6 (7): 15-29.

2009b Xamanizando a escrita: aspectos comunicativos da escrita ameríndia. Mana 15 (2): 509-528.

Marchán, Dévora M.

2005 Impacto socio-educativo de la misión salesiana entre los Yanomami del Alto Orinoco. Tesis de maestría, Universidad Pedagógica Experimental Libertador, Maracay.

Martínez, Rodrigo and Andrés Fernández

2010 Impacto social y económico del analfabetismo: modelo de análisis y estudio piloto. Documento de proyecto. 84 pp. Comisión Económica 
para América Latina y El Caribe, CEPAL (ONU)/Oficina Regional de Educación para América Latina y el Caribe (UNESCO), Santiago de Chile.

Ministerio de Educación

1988 Programa de educación intercultural bilingüe. Ministerio de Educación, Caracas.

Mosonyi, Esteban E.

1998 Veinte años de la educación intercultural bilingüe en Venezuela 19791998: logros, deficiencias y nuevos retos. In Régimen de Educación Intercultural Bilingüe: Diagnósticos y Propuestas 1998-2000, pp. 17-32. Dirección de Asuntos Indígenas/Ministerio de Educación, Caracas.

2008 Universidad Indígena de Venezuela. En Diversidad cultural $e$ interculturalidad en educación superior. Experiencias en América Latina, edited by Daniel Mato, pp. 427-436. Instituto Internacional de la UNESCO para la Educación Superior en América Latina y el Caribe, Caracas.

Mosonyi, Esteban E. and Francisco A. Rengifo

1982 Un enfoque interdisciplinario sobre los fundamentos teóricos y programáticos de la educación intercultural bilingüe en Venezuela. Anuario Indigenista XLII: 31-57.

Mosonyi, Esteban E. and Jorge C. Mosonyi

2000 El educador indígena ante las lenguas aborígenes. In Manual de lenguas indígenas de Venezuela, Tomo I, pp. 68-108, edited by esteban E. Mosonyi y Jorge C. Mosonyi. Serie Orígenes Vol. 2. Fundación Bigott, Caracas.

Moreno, Dario

2000 Siguiendo las huellas de la educación intercultural bilingüe en Amazonas. La Iglesia en Amazonas 21 (88): 20-25.

Pérez de Borgo, Luisa

2004 Educación superior indígena en Venezuela: una aproximación. 65 pp. Instituto Internacional de la UNESCO para la Educación Superior en América Latina y el Caribe/Ministerio de Educación Superior de la Olson, David R. República Bolivariana de Venezuela, Caracas.

1994 The world on paper. The conceptual and cognitive implications of writing and reading. $282 \mathrm{pp}$. Cambridge University Press, Cambridge.

Regnault, Blas A.

2005 La asistencia escolar de la población indígena venezolana. Notas de Población 31 (79): 263-298.

2006 Escuela y significados compartidos. Asistencia y permanencia escolar de la niñez y adolescencia indigena en Venezuela. 72 pp. Fondo de las Naciones Unidas para la infancia UNICEF, Caracas. 
Rogoff, B.

1981

Schooling and the development of cognitive skills. En Handbook of CrossCultural Psychology, edited by Harry C. Triandis y Alastair Heron, pp. 233294. Developmental Psychology Vol. IV. Allyn and Bacon, Boston.

Scribner, Syliva and Michael Cole

1981 The psychology of literacy. 355 pp. Harvard University Press, Cambridge. Sharp, Donald, Michael Cole and Charles Lave

1979 Education and cognitive development: The evidence from experimental research. $112 \mathrm{pp}$. Monographs of the Society for research in child development Vol. 44, No 1-2. University of Chicago Press for the Society for Research in Child Development, Chicago.

Street, Brian

1984 Literacy in theory and practice. 239 pp. Cambridge University Press, Cambridge.

Tassinari, Antonella I. and Clarice Cohn

2009 "Opening to the other": Schooling among the Karipuna and Mebengokré-Xikrin of Brazil. Anthropology \& Education Quarterly 40 (2): 150-169.

Vega, F.

2000 La educación intercultural bilingüe. Una tarea de todos. La Iglesia en Amazonas 88: 6-8.

Vidal, Lux (editor)

1992 Grafismo indígena: estudos de antropologia estética. 296 pp. Studio Nobel, São Paulo.

Vilaça, Aparecida

2002 Making kin out of others in Amazonia. Journal of the Royal Anthropological Institute 8 (2): 347-365.

2005 Chronically unstable bodies: reflections on Amazonian corporalities. Journal of the Royal Anthropological Institute 11 (3): 445-464.

Villa, E. P.

2000 Formación de maestros indígenas en educación prescolar en la Amazonia Venezolana. La Iglesia en Amazonas 87: 16-18.

Villalón, María E.

1994 Educación para indígenas en Venezuela: una crítica razonada. 48 pp. Documento de Trabajo No 9. Centro Venezolano de Investigaciones en Antropología y Población (CEVIAP), Caracas.

Viveiros de Castro, Eduardo B.

1998 Cosmological deixis and Amerindian perspectivism. Journal of the Royal Anthropological Institute 4 (3): 469-488.

$2002 \quad A$ inconstância da alma selvagem $e$ outros ensaios de antropologia. 552 pp. Cosac \& Naify, São Paulo. 
Whitehead, Neil L.

1992 Tribes make states and states make tribes: warfare and the creation of colonial tribes and states in northeastern South America, 1492-1820. in War in the tribal zone. Expanding states and indigenous warfare, edited by R. Brian Ferguson y Neil L. Whitehead, pp. 127-150. School of American Research Press, Santa Fe. 